\title{
Psychological Impacts of Students on Online Learning During the Pandemic COVID-19
}

\author{
Andi Wahyu Irawan ${ }^{1}$, Dwisona $^{1}$, Mardi Lestari ${ }^{3}$ \\ ${ }^{1}$ Universitas Mulawarman Indonesia, ${ }^{3}$ Universitas Tadulako Indonesia \\ andiwahyuirawan@fkip.unmul.ac.id
}

Submitted: 2020-04-29, Revised: 2020-05-14, Accepted: 2020-05-27

\begin{abstract}
The Indonesian government formally enforces rules of study, worship, and work from home from March 16, 2020. Minimizing and limiting meetings involving physical contact is an effort to reduce the spread of the COVID-19 virus. These conditions have implications for the effectiveness of the learning process in higher education. The purpose of this study was to identify the impact of student psychology on online learning during the COVID-19 pandemic. The research method uses a qualitative research type of phenomenology. The research subjects were 30 students of Mulawarman University who were interviewed via telephone. The research findings show that (1) students have started to get bored with online learning after the first two weeks of learning from home, (2) considerable anxiety on research subjects whose parents have low income, because they have to buy quotas to be able to participate in online learning, (3) mood or mood changes occur due to too many assignments and are considered ineffective by students. Suggestions and recommendations from this research are the need for severe efforts in assisting the psychological well-being of students through the involvement of counselors and psychologists.
\end{abstract}

Keywords: Pandemic COVID-19; Psychological Impacts of Students; Online Learning

\section{Introduction}

The 2019 coronavirus outbreak (COVID-19) has become an international concern since the first case occurred in Wuhan, Hubei Province, China, at the end of December 2019. The number surpassed the SARS case in 2003. The number of instances then increased exponentially, to spread throughout the world(Lai, Shih, Ko, Tang, \& Hsueh, 2020). Indonesia is projected to have a total population of 319 million by 2020. China, by 2018, the people will reach 1.393 billion, Wuhan is an area with a population of 11.08 million (Du et al., 2020). That number far exceeds the population of Indonesia. With a large population with an intense level of physical encounters, it will increase the potential for increasingly massive virus spread.

In early April, the Indonesian government set a strict policy through the rules of largescale social restrictions to reduce the spread of COVID-19. Progressive steps are taken to limit the spread of the virus through restrictions on human motion. In the field of education, learning from home is implemented, carried out online, and through Television Republik Indonesia (TVRI), which broadcasts educational broadcasts simultaneously, every day, at every level of education. However, it cannot be denied. Despite various progressive steps taken by the government to reduce transmission of COVID-19, community fear will always be there, resulting in erratic behavior. One study found that $16.5 \%$ reported symptoms of moderate to severe depression; $28.8 \%$ said symptoms of moderate to severe anxiety, and $8.1 \%$ reported moderate to critical stress levels. Furthermore, Wang found that in the first two weeks after the outbreak, women reported experiencing higher stress, anxiety, and depression compared to men (Wang et al., 2020). In line with research that says coronavirus affects some individuals emotionally, they experience fear of contracting the virus, feeling helpless and high negative stigma (Kumar \& Somani, 2020).

In another study found that during an outbreak, at the time he was researching about the H1NI virus, around $10 \%$ to $30 \%$ of the general public was quite worried about the possibility of contracting the virus(Han, Michie, Potts, \& Rubin, 2016). When compared to the SARS case that occurred in 2003, the more considerable panic occurred at the COVID-19 
because of global connectivity through social media and increasingly massive information dissemination. Overcoming mental health problems, the Chinese Government issued guidelines for psychological crisis emergency intervention for COVID-19 patients and health workers through the multi-disciplinary collaboration for the formation of mental health teams. China, as a country that has succeeded in reducing the rate of coronavirus spread in its homeland, needs to be used as a reference as a mitigation measure. An essential point of Chinese Government policy is multi-disciplinary collaboration. This means that not only is science closely related to viruses (exact), so the study of social-psychological perspectives on COVID-19, is still relevant for research.

The Ministry of Education and Culture of the Republic of Indonesia estimates that 34.5 percent of students are unable to access online education. Significant efforts are being made by governments and educational institutions at all levels to find practical solutions in online learning amid the COVID-19 outbreak. This action helps parents to accompany their child's education at home and at least reduce parents' concerns about the quality of online learning. A study shows that when students are not at school, for example, holidays or study at home, they are physically less active and have a longer time to use mobile phones, and so their use will also feel saturated, even with severe, mild stress (Brazendale et al., 2017).

The situation will get worse if they are prohibited from leaving the house without outdoor activities and lack of interaction with their peers. Bored, stressed, afraid of being exposed to viruses, the spread of false information (hoaxes), and worsening family financial conditions can occur. The burden of online lecture tasks is one of the contributing factors to students' stress levels, which requires them to use online media that they have just learned and must immediately understand. This is reinforced by research that found that public health emergencies can have many psychological effects on students, which can be expressed in the form of anxiety, fear, and anxiety (Sharp \& Theiler, 2018).

Based on Mulawarman University policy on March 18, 2020, which calls for all lecture activities to be carried out online, research is needed on the impact of online learning and solutive efforts in overcoming effects as part of research recommendations. This research is essential because in uncertain and uncertain situations when this outbreak will end, socialpsychological scientific research is needed to help find progressive steps in providing psychological welfare for affected communities, not only positive victims of COVID-19 but the community in general, in this study, especially students.

This pandemic carries not only the risk of death from a viral infection but also psychological stress for people throughout the world (Xiao, 2020). Continuous dissemination, strict isolation measures, and online learning problems at all levels of education are expected to affect mental health, including students. A study was conducted on the psychological effects of the COVID-19 epidemic on students in China, carried out quantitatively, with 7,143 respondents filling out a questionnaire (Cao et al., 2020). So far, there has been no detailed research on the psychological impact of students in implementing online learning during a pandemic outbreak. Therefore, this study aims to identify the psychological effects of students on online learning during the COVID-19 pandemic.

\section{Methods}

This research was conducted with a qualitative method of phenomenology type, which is an attempt to find out how the research subject's understanding of the experiences he experienced related to online learning. Phenomenology refers to a person's perception of the meaning of an event that is contrary to facts that exist outside the person

The research setting is broad in the subjective experience of each research subject. For the meaning of the research subject to the reality that he experienced, researchers find meaning, negotiate, and renegotiate the purpose with the subject under study. The implication is seen 
through the process of collecting data through unstructured interviews and documentation studies. Interviews were conducted by telephone to avoid physical meetings by government instructions for physical distancing during the COVID-19 outbreak. An unstructured interview was done so that the researcher could find more in-depth about the experience of the research subject, without depending on rigid indicators. Researchers focus on asking questions that fit the focus of research. To add data, a documentation study was conducted by analyzing the social media status of the research subjects.

The determination of research subjects is done by purposive sampling, which is a sampling technique by determining the desired research subject indicators, consisting of 30 research subjects, each consisting of 15 men and 15 women. Indicators for selecting research subjects are; (1) The research subjects are second-semester students of Mulawarman University, (2) conducting online learning in the zoom application (3) coming from outside Samarinda, (4) from the economic side, the research subjects are selected in two categories, namely underprivileged students and students economically capable. Affordable students whose parents earn twice the provincial minimum wage. Whereas underprivileged students are with the economic condition of the family whose parents' income is below 2.5 million rupiahs. The data found were analyzed using phenomenological analysis, namely phenomenal reduction, eidetic reduction, and transcendental reduction.

\section{Results and Discussion}

Since March 18, 2020, at Mulawarman University, all face-to-face lectures have turned into online learning. These changes have implications for various kinds in the academic community, which allegedly could have an impact on psychological conditions. Some of the research findings that we found in the field are described in the form of subtitles below:

1. Saturated with Online Learning

The data found shows that during the first two weeks, research subjects still felt comfortable with online learning. Even during the first online lecture meeting using the zoom application, students were happy because they could greet each other. In the second week, the excitement of online learning began to diminish. Students have started to question the effectiveness of online learning.

During the second week, students began to spread memes in the form of complaints against online learning. They update the status with a variety of claims, ranging from many tasks, quota runs out, and the condition of the internet network. A study of nursing students showed anxiety among participants related to the effects of the COVID-19 virus(Huang \& rong Liu, 2020). Such anxiety results in boredom in online learning. Research findings also indicate the emergence of irritability in research subjects in the people around them. Most of the participants stated that participants felt angry about the situation if there was a lot of interference from the environment and internet network disruption.

Psychological dynamics shows the background of the occurrence of boredom in students, caused by various social conditions that occur in their environment. Not only that, the increasing number of patients and suspected cases, as well as the growing number of countries affected by the outbreak, have raised fears of the public being infected in this outbreak, which has increased anxiety (Bao, Sun, Meng, Shi, \& Lu, 2020).

On the other hand, boredom is also caused by the increasing distance between people, as a result of the policy of physical distancing and the prohibition to leave the house. Anxiety then arises and gets worse because there is no interpersonal communication (Galea, Merchant, \& Lurie, 2020). Online learning that makes students communicate through gadget intermediaries makes the interaction between one individual and other individuals lack the meaning of non-verbal communication. The absence of these interactions, coupled with restrictions on physical meetings, make students bored. 
According to a study, initially, individuals feel happy with a long holiday because they can rest more and do nothing. Over time, according to Wilson, individuals will feel bored because they can not leave the house and do nothing. This research shows that something that is done statically, it will cause boredom. This condition applies during the COVID-19 outbreak (Williams, Armitage, Tampe, \& Dienes, 2020).

Other research shows that boredom displays low self-control (Mugon, Struk, \& Danckert, 2018). So someone who is quickly bored while studying at home has low selfcontrol. This shows that individuals who tend to be drilled are unable to arrange, guide, regulate, and direct the forms of behavior that can bring it in a positive direction.

2. Worried About Parents' Earnings

The data findings show that anxiety in middle and lower economic families is more significant than fear in middle and upper economic families. Research subjects who come from families who are economically capable, show fewer complaints when compared to families who are financially unable. This finding is reinforced by the results of research that found that there are anxiety in humans about future work during the COVID-19 outbreak, especially economically vulnerable families (Yazid \& Lie, 2020).

Research subjects showed complaints on internet quota purchases, which had to be used for online learning. Students feel anxious about their parents' income, which is reduced because of the physical distancing policy and requires their parents to be at home so that their income is reduced. Access to online learning is ultimately dominated by students whose parents are economically capable. In contrast, students who come from below-average family economic conditions feel anxious because they cannot afford to buy internet quota, which will result in the final grade of the course.

All research subjects depend on the parents' income. So that when parents' income decreases, it will cause student anxiety because they have to buy a quota, as a logical consequence to follow the lecture process and get the best value. Because of the plague, some families will lose their source of income, and students feel anxious about paying their school fees (Gonzalez, Karpman, Kenney, \& Zuckerman, 2020).

A study also shows that the stability of family income is also a significant factor in anxiety experienced by students during the COVID-19 crisis, which can be explained by increased psychological and economic stress (Liu, 2013). All research subjects chose to return to their hometowns to reduce the burden on family expenses. According to some studies, living together with parents at the time of the COVID-19 outbreak will reduce anxiety and psychological problems. By living with parents, according to the research subjects, they can also help parents, both in terms of family finances and help others.

For research subjects who are in the middle to lower economic conditions, helping parents is done by gardening or doing activities that make money, or for women, assisting mothers at home to cook (Gentili et al., 2020). As for research subjects with middle to upper economic conditions, go home to the yard to treat feelings of longing (Woodgate, Tailor, Tennent, Wener, \& Altman, 2020).

A study conducted in Japan showed that living in urban areas was more conducive to reducing student anxiety than in rural areas during the COVID-19 outbreak (Shigemura, Ursano, Morganstein, Kurosawa, \& Benedek, 2020). According to him, the imbalance of economic, cultural, and educational resources between urban and rural areas is the cause. The urban economy is relatively prosperous and provides citizens with better material security. This study shows that anxiety is higher in rural communities compared to urban communities during the COVID-19 outbreak. They live in areas that have limited internet network access, difficulty in earning income, and the high cost of necessities due to limited road access. To buy internet quota, students are faced with reality with the economic condition of the family. If though when they live in the city, additional work can be done to supplement their income, for example, 
becoming an online motorcycle taxi or working part-time. While in the village, they are confused because they do not generate revenue that can cover all needs. This condition causes anxiety in students.

3. Emotional Disorders

Emotional disorders, characterized by moods and mood swings. Research subjects experienced emotional disturbances due to too many tasks, and they considered that the pattern was not sufficient. The second week since the implementation of the learning policy from home, the subject of research complained about the assignment of too many. Some research subjects even assume that lecturers are not wise in determining useful learning patterns.In the online learning process, research subjects complained about the lack of social support from their friends. Lack of physical interaction is one reason. Students are busy with themselves to complete their assignments.

In line with research findings that show that social support can reduce psychological distress during epidemics (Yin-xia et al., 2005). These results indicate that practical and robust social support is needed during public health emergencies. Other research also shows that social support is negatively correlated with student anxiety, which is consistent with previous findings (Thompson, McBride, Hosford, \& Halaas, 2016).

Online learning that limits physical interaction causes no social interaction, so verbal and non-verbal communication is not used correctly. In the learning conditions, students complain about situations that burden them in learning. Lack of social support makes students experience emotional disturbances. In the end, learning was felt to be less effective, primarily when two weeks after education was carried out. To reduce emotional disturbances, some students try to build communication with lecturers to tolerate tasks that they think are so heavy.

\section{Conclusions and Suggestions}

The research findings show that the psychological impact of students on online learning during the COVID-19 pandemic, namely (1) students are bored with online learning after the first two weeks of learning from home, (2) considerable anxiety on research subjects whose parents have low income, because they have to buy a quota to be able to take part in online learning, and (3) emotional disturbances are indicated by changes in mood or mood caused by too many assignments that are considered ineffective by students.

Students' mental health is greatly affected when faced with a public health emergency, and they need attention, help, and support from the community, family, and tertiary institutions. It is recommended that the government and schools should collaborate to solve this problem by providing psychological services. Psychologists and counselors can work to offer online services to overcome the effects of COVID-19. For future researchers, it is recommended to research a solutive effort to overcome the psychological impact of the COVID-19 pandemic

\section{References}

Bao, Y., Sun, Y., Meng, S., Shi, J., \& Lu, L. (2020). 2019-nCoV epidemic: address mental health care to empower society. The Lancet, 395(10224), e37-e38.

Brazendale, K., Beets, M. W., Weaver, R. G., Pate, R. R., Turner-McGrievy, G. M., Kaczynski, A. T., ... von Hippel, P. T. (2017). Understanding differences between summer vs. school obesogenic behaviors of children: the structured days hypothesis. International Journal of Behavioral Nutrition and Physical Activity, 14(1), 100.

Cao, W., Fang, Z., Hou, G., Han, M., Xu, X., Dong, J., \& Zheng, J. (2020). The psychological impact of the COVID-19 epidemic on college students in China. Psychiatry Research, 112934.

Du, Z., Wang, L., Cauchemez, S., Xu, X., Wang, X., Cowling, B. J., \& Meyers, L. A. (2020). 
Risk of 2019 novel coronavirus importations throughout China prior to the Wuhan quarantine. MedRxiv.

Galea, S., Merchant, R. M., \& Lurie, N. (2020). The mental health consequences of COVID19 and physical distancing: The need for prevention and early intervention. JAMA Internal Medicine.

Gentili, D., Bardin, A., Ros, E., Piovesan, C., Ramigni, M., Dalmanzio, M., ... Cinquetti, S. (2020). Impact of Communication Measures Implemented During a School Tuberculosis Outbreak on Risk Perception among Parents and School Staff, Italy, 2019. International Journal of Environmental Research and Public Health, 17(3), 911.

Gonzalez, D., Karpman, M., Kenney, G. M., \& Zuckerman, S. (2020). Hispanic Adults in Families with Noncitizens Disproportionately Feel the Economic Fallout from COVID19.

Han, Y. K. J., Michie, S., Potts, H. W. W., \& Rubin, G. J. (2016). Predictors of influenza vaccine uptake during the 2009/10 influenza A H1N1v ('swine flu') pandemic: Results from five national surveys in the United Kingdom. Preventive Medicine, 84, 57-61.

Huang, L., \& rong Liu, H. (2020). Emotional responses and coping strategies of nurses and nursing college students during COVID-19 outbreak. MedRxiv.

Kumar, A., \& Somani, A. (2020). Dealing with Corona virus anxiety and OCD. Asian Journal of Psychiatry, 102053.

Lai, C.-C., Shih, T.-P., Ko, W.-C., Tang, H.-J., \& Hsueh, P.-R. (2020). Severe acute respiratory syndrome coronavirus 2 (SARS-CoV-2) and corona virus disease-2019 (COVID-19): the epidemic and the challenges. International Journal of Antimicrobial Agents, 105924.

Mugon, J., Struk, A., \& Danckert, J. (2018). A failure to launch: Regulatory modes and boredom proneness. Frontiers in Psychology, 9, 1126.

Sharp, J., \& Theiler, S. (2018). A review of psychological distress among university students: Pervasiveness, implications and potential points of intervention. International Journal for the Advancement of Counselling, 40(3), 193-212.

Shigemura, J., Ursano, R. J., Morganstein, J. C., Kurosawa, M., \& Benedek, D. M. (2020). Public responses to the novel 2019 coronavirus $(2019-\mathrm{nCoV})$ in Japan: mental health consequences and target populations. Psychiatry and Clinical Neurosciences, 74(4), 281.

Thompson, G., McBride, R. B., Hosford, C. C., \& Halaas, G. (2016). Resilience among medical students: the role of coping style and social support. Teaching and Learning in Medicine, $28(2), 174-182$.

Wang, C., Pan, R., Wan, X., Tan, Y., Xu, L., Ho, C. S., \& Ho, R. C. (2020). Immediate psychological responses and associated factors during the initial stage of the 2019 coronavirus disease (COVID-19) epidemic among the general population in China. International Journal of Environmental Research and Public Health, 17(5), 1729.

Williams, S. N., Armitage, C. J., Tampe, T., \& Dienes, K. (2020). Public perceptions and experiences of social distancing and social isolation during the COVID-19 pandemic: A UK-based focus group study. MedRxiv.

Woodgate, R. L., Tailor, K., Tennent, P., Wener, P., \& Altman, G. (2020). The experience of the self in Canadian youth living with anxiety: A qualitative study. PloS One, 15(1), $\mathrm{e} 0228193$.

Xiao, C. (2020). A novel approach of consultation on 2019 novel coronavirus (COVID-19)- 
related psychological and mental problems: structured letter therapy. Psychiatry Investigation, 17(2), 175.

Yazid, S., \& Lie, L. D. J. (2020). Dampak Pandemi Terhadap Mobilitas Manusia di Asia Tenggara. Jurnal Ilmiah Hubungan Internasional, 75-83.

Yin-xia, B. A. I., GEGENTUYA, H. A. I., Hu, L. I. U., Zhen-hua, W., Wen-rui, W. A., \& Zhigang, N. G. (2005). Correlation Between Psychological Changes of The Community Cro wd and The Social Support in Grave Public Health Event [J]. Nei Moivgol Medical Journal, 4. 
